\title{
Potensi Guru-guru Kabupaten Lombok Barat dalam Mengembangkan Profesinya melalui Penyusunan Karya Ilmiah
}

\author{
Joni Rokhmat $^{{ }^{*}}$, Edy Herianto ${ }^{1}$, Wildan ${ }^{1}$ \\ ${ }^{\text {IP }}$ rogram Studi Administrasi Pendidikan, Program Pascasarjana, Universitas Mataram, Mataram, Indonesia
}

*Corresponding Author: Joni Rokhmat, Universitas

Mataram, Mataram, Indonesia; Email:joni.fkip@unram.ac.id

\begin{abstract}
Abstrak: Kegiatan pengabdian kepada masyarakat ini bertujuan menelusuri potensi para guru dalam mengembangkan profesinya melalui penyusunan karya ilmiah dan memberi arahan dalam menyusun karya ilmiah. Pengabdian ini dilakukan dengan metode ceramah dan tanya jawab, serta latihan kerja (workshop) dan melibatkan 30 orang guru Sekolah Menengah Atas (SMA) di Kabupaten Lombok Barat. Hasil diskusi menunjukkan bahwa guru-guru tersebut sangat antusias mengikuti kegiatan tetapi sekalipun kegiatan ini bukan hal baru mayoritas masih belum memahami bagaimana penyusunan proposal, instrumen, hingga melaksanakan penelitian tindakan kelas, serta bagaimana menulis artikel ilmiah, khususnya artikel hasil penelitian. Sementara, hasil analisis angket menunjukkan bahwa semua peserta kegiatan pengabdian ini belum memiliki publikasi ilmiah sekalipun beberapa di antaranya sudah memerlukannya. Jadi pada dasarnya guru-guru tersebut berpotensi mengembangkan profesinya melalui penyusunan karya ilmiah. Sebagai kendala adalah belum mengetahui bagaimana menyusun karya ilmiah, serta tidak ada waktu karena beban kerja cukup masif. Terhadap kegiatan ini, mereka menyarankan agar kegiatan ini dilaksanakan secara rutin, sekali hingga dua kali dalam setahun pada tingkat sekolah hingga tingkat Musyawarah Guru Mata Pelajaran (MGMP), termasuk perlunya menjalin kerjasama dengan perguruan tinggi.
\end{abstract}

Kata kunci: pengabdian masyarakat, proposal penelitian, penelitian tindakan kelas, artikel ilmiah

\section{Pendahuluan}

Sebagai bagian dari pelaksanaan Tri Dharma Perguruan Tinggi adalah kegiatan Pengabdian Kepada Masyarakat (PKM). Sesuai dengan permenristekdikti nomor 44 tahun 2015 tentang Kerangka Kualifikasi Nasional Indonesia (KKNI) Pasal (1) ayat 12 dinyatakan bahwa pengabdian kepada masyarakat merupakan kegiatan sivitas akademika yang memanfaatkan ilmu pengetahuan dan teknologi untuk memajukan kesejahteraan masyarakat dan mencerdaskan kehidupan bangsa. Selanjutnya, pada Pasal (55) ayat (2) disebutkan bahwa hasil pengabdian kepada masyarakat dapat berupa penyelesaian masalah yang dihadapi masyarakat dengan memanfaatkan keahlian sivitas akademika yang relevan, pemanfaatan teknologi tepat guna, bahan pengembangan ilmu pengetahuan dan teknologi, atau pemanfaatan bahan ajar atau modul pelatihan untuk pengayaan sumber belajar.

Dalam rangka meningkatkan jabatan fungsional dan kepangkatan, salah satu yang perlu dilakukan seorang guru adalah meningkatkan kemampuan dan keterampilannya dalam menyusun karya ilmiah sesuai dengan bidang keahliannya. Sesuai dengan permendiknas nomor 35 tahun 2010, tentang petunjuk teknis pelaksanaan Jabatan Fungsional Guru dan Angka Kreditnya, jumlah angka kredit yang harus dikumpulkan seorang guru dari sub-unsur publikasi ilmiah dan/atau karya inovatif, serta jenis publikasi yang wajib ada (minimal satu publikasi) saat mengajukan kenaikan dari satu jabatan ke jabatan lain yang setingkat lebih tinggi telah diatur sebagaimana diperlihatkan dalam Tabel 1.

Tabel 1 memperlihatkan bahwa seorang guru pada jabatan Guru Muda pada golongan IIId ketika mengusulkan kenaikan jabatan dan/atau 
pangkat diwajibkan mengumpulkan sub-unsur publikasi ilmiah yang merupakan karya tulis hasil laporan penelitian. Selanjutnya, dalam tabel itu diperlihatkan besaran kredit yang harus dikumpulkan untuk sub-unsur ini, apabila seorang guru mengusulkan kenaikan pangkat dari Guru Muda IIId ke Guru Madya IVa, Guru Madya IVa ke Guru Madya IVb, Guru Madya IVb ke Guru Madya IVc, Guru Madya IVc ke Guru Utama IVd, serta dari Guru Utama IVd ke Guru Utama IVe. Jumlah minimal sub-unsur ini, masing-masing 8 (delapan), 12 (dua belas), 12 (dua belas), 14 (empat belas), dan 20 (dua puluh). Sub-unsur publikasi ilmiah ini menurut tingkatan dari yang cukup diseminarkan di tingkat sekolah dan disimpan di perpustakaan hingga publikasi ilmiah yang diterbitkan/dipublikasikan dalam majalah/jurnal ilimiah tingkat nasional yang terakreditasi.

Permendiknas di atas berimplikasi bahwa ketika seorang guru yang saat ini berada pada jabatan Guru Muda dengan golongan IIId tidak akan dapat mengajukan kenaikan jabatan dan/atau pangkat jika ia tidak pernah melakukan penelitian yang selanjutnya dilaporkan sebagai karya ilmiah yang sekurang-kurangnya dipublikasikan pada tingkat perpustakaan sekolah. Di pihak lain, fakta memperlihatkan bahwa sepengetahuan tim pengabdian, hasil studi pendahuluan yang dilakukan secara informal, pada praktik pembelajaran di kelas secara disadari maupun tidak dalam berupaya meningkatkan kualitas proses pembelajaran siswanya, cukup banyak guru yang selalu membuat perlakuan-perlakuan yang baru atau paling tidak membuat perlakuan berbeda dari sebelumnya yang dipandang lebih efektif daripada perlakuan sebelumnya.Tindakan tersebut sebenarnya dapat diadmistrasikan dan dianalisis dan dilaporkan sebagai dokumen penelitian yang pada gilirannya dapat dikembangkan sebagai karya ilmiah untuk menunjang peningkatan jabatan fungsionalnya. Namun demikian, selama ini kegiatan itu tidak diorganisir menjadi sebuah penelitian dan karya ilmiah.

\section{Tabel 1 Jenis Publikasi Wajib Dibuat Guru}

Berdasarkan Golongan dan Jabatan (Nuh, 2010)

\begin{tabular}{lcccc}
\hline Dari Jabatan & Ke Jabatan & $\begin{array}{c}\text { Sub-unsur } \\
\text { pengembangan } \\
\text { diri }\end{array}$ & $\begin{array}{c}\text { Sub-unsur publikasi } \\
\text { ilmiah dan atau } \\
\text { karya inovatif }\end{array}$ & $\begin{array}{c}\text { Macam publikasi ilmiah yang wajib } \\
\text { ada (minimal satu publikasi) }\end{array}$ \\
\hline $\begin{array}{l}\text { Guru Pertama } \\
\text { golongan IIIa }\end{array}$ & $\begin{array}{c}\text { Guru Pertama } \\
\text { golongan IIIb }\end{array}$ & 3 (tiga) & - & - \\
\hline
\end{tabular}

Secara umum para guru tidak mengetahui atau lebih tepat tidak terbiasa menyusun karya ilmiah berbasis hasil penelitian dan hal ini sudah berjalan cukup lama sehingga mereka terlanjur merasa nyaman pada kondisi seperti ini. Untuk mengubahnya, kepada mereka perlu diberikan stimulus yang cukup kuat untuk menyadarkan bahwa mereka pada dasarnya mampu dan memiliki peluang untuk melakukan kegiatan penelitian sebagai basis dalam menyusun karya ilmiah berupa artikel untuk dipublikasikan pada jurnal nasional lokal atau nasional terakreditasi, atau lebih tinggi lagi dipublikasikan pada jurnal internasional bereputasi.

Sementara itu, di beberapa sekolah, upaya pelatihan karya ilmiah juga sudah dilakukan para guru melalui kerjasama dengan sejumlah dosen di Universitas Mataram. Namun demikian, fakta menunjukkan dari sejumlah guru yang mengikuti pelatihan tersebut, sepengetahuan penulis, tidak lebih dari $10 \%$ atau bahkan tidak ada sama sekali guru yang melanjutkannya hingga tersusun karya ilmiah baik dari hasil kajian pustaka maupun dari hasil kegiatan penelitian, khususnya penelitian tingakan kelas.

Melihat situasi ini, kami para dosen di program studi Magister Administrasi Pendidikan, Universitas Mataram, merasa terpanggil untuk mengadakan kegiatan pendampingan penyusunan karya ilmiah bagi para guru pada jenjang pendidikan menengah, yaitu pada guru Sekolah Menengah Atas (SMA). Kegiatan ini adalah pendampingan penyusunan atau penyempurnaan karya ilmiah terutama sebagai hasil dari penelitian tindakan kelas, serta menyusunnya sesuai dengan template jurnal yang dituju untuk publikasi, baik pada jurnal lokal, nasional terdaftar, nasional terakreditasi, atau bahkan pada jurnal internasional bereputasi terindeks scopus. Untuk saat ini, kegiatan pendampingan ini, pelaksanaannya dibatasi pada guru-guru SMA di Kabupaten Lombok Barat. 


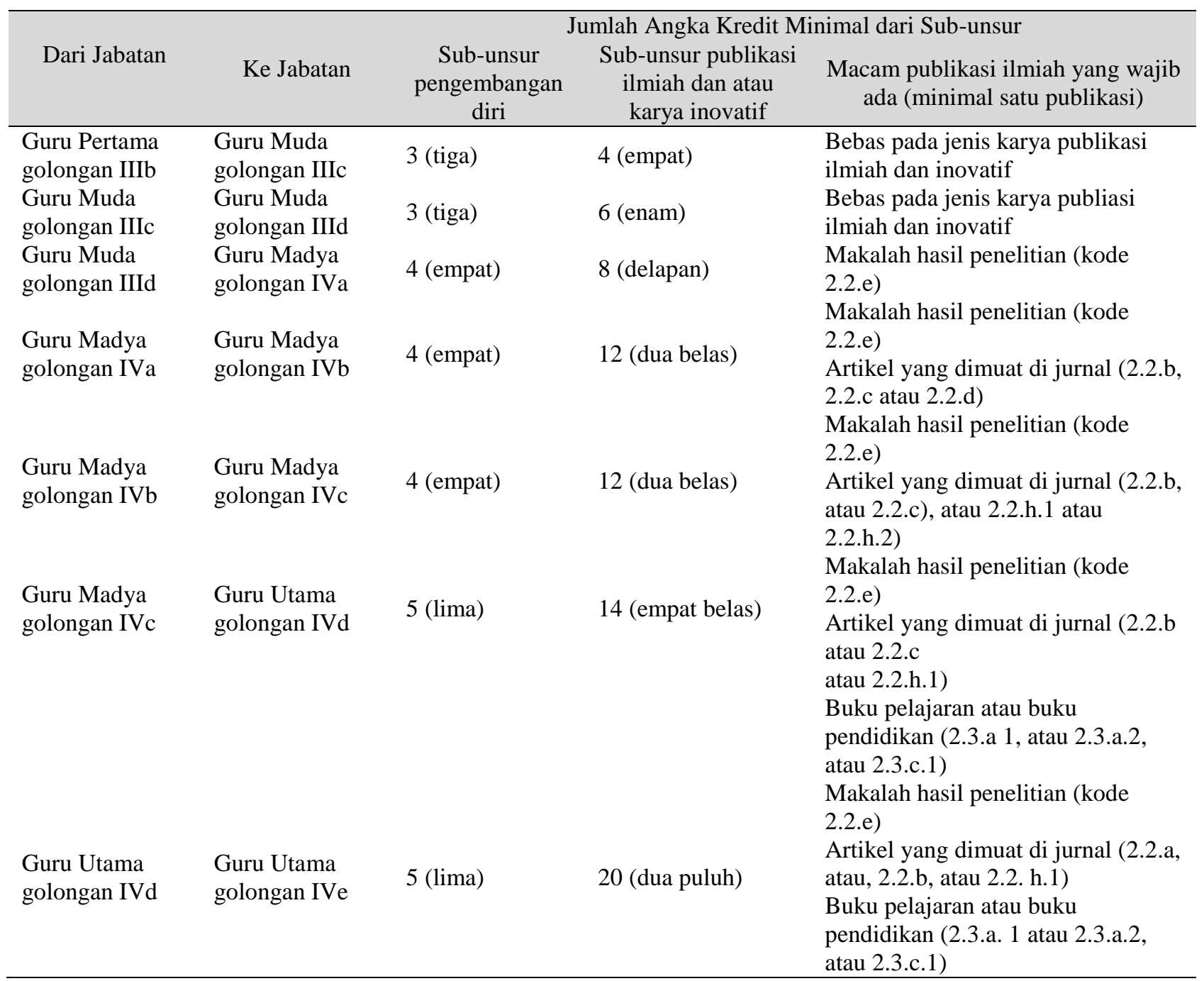

Keterangan:

2.2.b = Membuat karya tulis berupa laporan hasil penelitian pada bidang pendidikan di sekolah/madrasahnya, diterbitkan/ dipublikasikan dalam majalah/jurnal ilmiah tingkat nasional yang terakreditasi

2.2.c $=$ Membuat karya tulis berupa laporan hasil penelitian pada bidang pendidikan di sekolah/madrasahnya, diterbitkan/ dipublikasikan dalam majalah/jurnal ilmiah tingkat provinsi

2.2.d = Membuat karya tulis berupa laporan hasil penelitian pada bidang pendidikan di sekolah/madrasahnya, diterbitkan/ dipublikasikan dalam majalah ilmiah tingkat kabupaten/ kota

2.2.e $=$ Membuat karya tulis berupa laporan hasil penelitian pada bidang pendidikan di sekolah/madrasahnya, diseminarkan di sekolah/ madrasahnya, disimpan di perpustakaan

2.2.h.1 = Membuat artikel ilmiah dalam bidang pendidikan formal dan pembelajaran pada satuan pendidikannya dan dimuat di jurnal tingkat nasional yang terakreditasi

2.2.h.2 = Membuat artikel ilmiah dalam bidang pendidikan formal dan pembelajaran pada satuan pendidikannya dan dimuat di jurnal tingkat nasional yang tidak terakreditasi/tingkat provinsi

2.3.a.1 = Buku pelajaran yang lolos penilaian oleh BSNP.

2.3.a.2 = Buku pelajaran yang dicetak oleh penerbit dan ber ISBN

2.3.c.1 = Buku dalam bidang pendidikan dicetak oleh penerbit dan ber-ISBN

Metode

Pendampingan ini menggunakan metode ceramah dan tanya-jawab, latihan kerja (workshop) tentang penyusunan laporan penelitian, penulisan artikel hasil kajian pustaka, penulisan artikal hasil penelitian untuk diterbitkan pada jurnal ilmiah pendidikan untuk pengembangan pendidikan SMA, serta evaluasi yang dilakukan pada bagian akhir 
kegiatan dengan cara mengidentifikasi keterampilan para guru tentang kemampuannya dalam menyusun karya ilmiah yang mencakup kemampuan menyusun laporan penelitian, artikel hasil kajian pustaka, serta artikel hasil penelitian untuk diterbitkan pada jurnal ilmiah.

Selain itu, kepada para peserta pendampingan para peserta diminta untuk menyerahkan hasil kinerjanya. Keberhasilan kegiatan ini dapat dilihat dari banyak sedikitnya aspek positif dan aspek negatif yang dikemukakan oleh peserta dan dari hasil identifikasi kemampuan dan keterampilan para guru tentang penyusunan karya ilmiah, yang mencakup penyusunan laporan penelitian, serta penulisan artikel hasil kajian pustaka dan hasil penelitian tersebut.

\section{Hasil dan Pembahasan}

Pembahasan hasil kegiatan pengabdian akan difokuskan pada respon para guru terhadap hasil kegiatan pengabdian ini dan angket profil potensi pengembangan karya ilmiah guru. Hasil respon langsung meliputi pengakuan pengembangan dan/atau peningkatan pengetahuan mengenai: (1) penyusunan proposal penelitian tindakan kelas (PTK), (2) penyusunan instrumen PTK, (3) strategi pelaksanaan PTK, (4) penulisan artikel hasil penelitian, dan (5) pembukaan jurnal pendidikan hasil penelitian. Sementara itu, hasil angket meliputi profil guru-guru di kabupaten Lombok Barat berkenaan dengan potensinya dalam kepemilikan karya tulis ilmiah dan/atau dalam mengembangkan karya ilmiah baik melalui kajian pustaka maupun melalui jalur penelitian, khususnya PTK.

Dalam kegiatan pengabdian ini, tim pengabdian menyajikan materi tentang penyusunan karya ilmiah baik sebagai hasil penelitian maupun kajian pustaka. Dalam presentasi ini juga disajikan penyusunan proposal penelitian tindakan kelas (PTK). Selanjutnya, pada bagian akhir kegiatan, tim pengabdian memberikan angket kepada para peserta untuk menjaring informasi peta dan potensi publikasi ilmiah bagi para guru di kabupaten Lombok Barat. Hasil angket tersebut dalam bentuk ringkas ditampilkan dalam Tabel 2 sampai dengan Tabel 6. Tabel 2 menyajikan persentase setiap pilihan peserta berkenaan dengan kondisi publikasi dan berbagai alasan bagi para guru yang belum memiliki publikasi baik sudah ataupun belum memerlukannya. Selain itu, juga menyajikan persentase pilihan tentang respon peserta terhadap kegiatan pengabdian ini beserta beberapa saran konstruktif untuk pengembangan karya ilmiah lebih lanjut.

Tabel 3 menyajikan daftar saran peserta terhadap kegiatan lanjutan pengabdian kepada masyarakat ini. Selanjutnya, Tabel 4 memaparkan daftar alasan lain mengapa peserta pengabdian belum memerlukan publikasi ilmiah sedangkan Tabel 5 menyajikan daftar alasan lain mengapa peserta pengabdian belum memiliki publikasi ilmiah meskipun sudah memerlukannya. Terakhir, Tabel 6 memperlihatkan daftar draf atau rancangan judul penelitian bagi peserta kegiatan pengabdian ini yang diajukan oleh para peserta kegiatan pengabdian ini, baik secara individu maupun berkelompok.

Tabel 2 Persentase Jawaban Peserta Pengabdian terhadap Angket

\begin{tabular}{|c|c|c|c|c|c|c|c|c|c|c|c|c|c|}
\hline \multirow{3}{*}{ Atribut } & \multicolumn{12}{|c|}{ ANGKET, NOMOR } & \\
\hline & \multicolumn{2}{|c|}{1} & \multicolumn{6}{|c|}{2} & \multicolumn{2}{|c|}{3} & \multicolumn{2}{|c|}{4} & \\
\hline & $\mathrm{a}$ & $\mathrm{b}$ & $\mathrm{a}$ & $\mathrm{b}$ & $\mathrm{c}$ & $\mathrm{d}$ & $\mathrm{E}$ & $\mathrm{f}$ & $\mathrm{a}$ & $\mathrm{b}$ & $\mathrm{a}$ & $\mathrm{b}$ & \\
\hline Persentase $(\%)$ & 0 & 100 & 0 & 0 & 0 & 0 & 0 & 0 & 0 & 0 & 87 & 4 & \\
\hline \multirow{2}{*}{ Atribut } & \multicolumn{2}{|c|}{5} & \multicolumn{3}{|c|}{6} & \multicolumn{2}{|c|}{7} & \multicolumn{2}{|c|}{8} & \multicolumn{4}{|c|}{9} \\
\hline & $\mathrm{a}$ & $\mathrm{b}$ & $\mathrm{a}$ & $\mathrm{b}$ & $\mathrm{c}$ & $\mathrm{a}$ & $\mathrm{B}$ & $\mathrm{a}$ & $\mathrm{b}$ & $\mathrm{a}$ & $\mathrm{b}$ & $\mathrm{c}$ & $\mathrm{d}$ \\
\hline Persentse $(\%)$ & 35 & 26 & 9 & 61 & 22 & 22 & 78 & 43 & 48 & 17 & 61 & 13 & 13 \\
\hline \multirow{2}{*}{ Atribut } & & 10 & \multicolumn{3}{|c|}{11} & & & & & & & & \\
\hline & $\mathrm{a}$ & b & $\mathrm{c}$ & $\mathrm{a}$ & $\mathrm{b}$ & & & & & & & & \\
\hline Persentase (\%) & 74 & 30 & 0 & 39 & 65 & & & & & & & & \\
\hline
\end{tabular}




\section{Tabel 3 Daftar Saran Peserta terhadap Kegiatan Pengabdian Selanjutnya}

\begin{tabular}{|c|c|}
\hline Peserta & 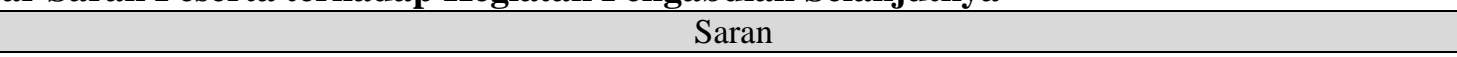 \\
\hline 1 & $\begin{array}{l}\text { Adanya tindak lanjut bagi guru untuk pendampingan proses penyusunan PTK agar lebih termotivasi } \\
\text { untuk menulis artikel }\end{array}$ \\
\hline 3 & $\begin{array}{l}\text { Adanya tindak lanjut pendampingan bagi guru untuk meningkatkana proses penyusunan karya ilmiah } \\
\text { atau PTK }\end{array}$ \\
\hline 4 & Lebih semangat \\
\hline 5 & Perlu penambahan frekuensi kegiatan yang ada kaitannya dengan penulisan KTI dll. \\
\hline 6 & $\begin{array}{l}\text { Dengan adanya kegiatan pendampingan karya tulis ilmiah kita dapat termotivasi untuk menulis, di } \\
\text { samping kita bisa menunjukkan prestasi pengembangan diri, tetapi perlu pembimbingan secara rutin } \\
\text { dalam proses penulisan supaya karya tulisnya sempurna }\end{array}$ \\
\hline Peserta & Saran \\
\hline 7 & Kegiatan ini sangat dibutuhkan oleh guru akan tetapi seringkali tidak ada kegiatan lanjut \\
\hline 8 & $\begin{array}{l}\text { Kegiatan ini sangat dibutuhkan oleh guru tetapi sayangnya kegiatan seperti ini kurang maksimal } \\
\text { (monitoring dan evaluasi) pelaksanaannya sehingga hasilnya belum nampak }\end{array}$ \\
\hline 9 & Tingkatkan pelatihan untuk pembuatan karya ilmiah \\
\hline 11 & Adanya tindak lanjut dalam pendampingan proses penyusunan karya tulis ilmiah sampai pada publikasi \\
\hline 12 & Lebih ditambah variasi dalam penyampaian materi agar prosesnya jauh leih aktif \\
\hline 13 & Kegiatan ini sangat bagus supaya lebih sering diadakan pendampingan \\
\hline 14 & Mampu meningkatkan penambahan ide dan karya atas kemampuan sendiri \\
\hline 15 & $\begin{array}{l}\text { Pendampingan langsung akan lebih efektif untuk memonitoring kendala-kendala dalam proses } \\
\text { tersebut. Kedua, perguruan tinggi perlu bekerjasama dengan sekolah untuk kegiatan / proses } \\
\text { selanjutnya }\end{array}$ \\
\hline 16 & $\begin{array}{l}\text { Berharap untuk memrogramkan kegiatan pendampingan karya tulis baik di tingkat sekolah maupun } \\
\text { MGMP setiap tahun dua kali }\end{array}$ \\
\hline 17 & Mengharapkan agar kegiatan pendampingan sesering mungkin dan sampai tuntas \\
\hline 18 & $\begin{array}{l}\text { (1) Waktu pelaksanaan agar lebih tepat dan tidak hanya sehari tetapi berkala dan berkelanjutan, (2) } \\
\text { perlu ada informasi awal agar peserta lebih siap }\end{array}$ \\
\hline 21 & Agar waktu pelaksanaan lebih dikondisikan \\
\hline 22 & Kami berharap agar program pendampingan ini terus berlanjut \\
\hline
\end{tabular}

\section{Tabel 4 Daftar Alasan Lain Peserta Mengapa Belum Memerlukan Publikasi Ilmiah}

\begin{tabular}{cl}
\hline Peserta & \multicolumn{1}{c}{ Alasan } \\
\hline 9 & Belum termotivasi untuk menyusun karya ilmiah \\
10 & Malas untuk memulai \\
15 & Kurang termotivasi dan belum ada keharusan \\
16 & Masih mencari teknik untuk memulai menulis agar dapat lebih efektif dan efisien \\
17 & Pada dasarnya berkeinginan menulis tetapi masih bingung untuk memulai \\
20 & Sibuk dengan pekerjaan rutin guru \\
\hline
\end{tabular}

\begin{tabular}{|c|c|}
\hline Peserta & Alasan \\
\hline 12 & $\begin{array}{l}\text { Sudah menulis dalam bentuk tugas akhir kuliah (skripsi), jenis penelitian tindakan kelas, dan masih } \\
\text { pada tahap konsultasi dengan dosen untuk upload ke jurnal nasional }\end{array}$ \\
\hline 14 & Butuh membaca dan menulis untuk menjadi sumber inspirasi agar mudah memuat karya ilmiah \\
\hline 21 & Bingung untuk memulai menulis karya ilmiah \\
\hline 22 & Kesulitan dalam penerapan rumus yang dipakai pada pengolahan data \\
\hline 23 & Belum ada yang mendampingi \\
\hline
\end{tabular}

\section{Tabel 6 Daftar Draf Judul Penelitian Tindakan Kelas (PTK)}

\begin{tabular}{cl}
\hline No & \multicolumn{1}{c}{ Draf Judul PTK } \\
\hline 1 & Penggunaan metode tutor sebaya untuk meningkatkan hasil belajar Microsoft word 2007 di kelas X MIPA 1 \\
2 & Penggunaan media pembelajaran berbasis ADOBE FLASH terhadap minat belajar matematika \\
3 & Upaya meningkatkan motivasi belajar siswa kelas XI IPS 1 dengan menggunakan metode NHT berbantuan \\
\hline & Kartu Soal di SMAN 1 Lembar \\
\hline
\end{tabular}




\begin{tabular}{|c|c|}
\hline No & Draf Judul PTK \\
\hline 4 & $\begin{array}{l}\text { Penerapan model pembelajaran Jigsaw untuk meningkatkan kemampuan kolaboratif siswa pada materi sistem } \\
\text { peredaran darah manusia kelas XI SMAN } 1 \text { Lembar tahun ajaran 2017/2018 }\end{array}$ \\
\hline 5 & Meningkatkan keterampilan literasi siswa kelas XI SMAN 1 Lembar melalui Teks Cerita Pendek \\
\hline 6 & $\begin{array}{l}\text { Meningkatkan kemampuan siswa memproduksi teks editorial melalui model PJBL di kelas XII MIPA } 1 \\
\text { SMAN 1 Lembar tahun } 2017\end{array}$ \\
\hline 7 & $\begin{array}{l}\text { Penggunaan metode eksperimen untuk meningkatkan pemahaman konsep sifat kaligatif larutan pada siswa } \\
\text { kelas XII MIPA SMAN } 1 \text { Lembar tahun pelajaran 2017/2018 }\end{array}$ \\
\hline 8 & $\begin{array}{l}\text { Penerapan bidang bimbingan konseling di SMAN } 1 \text { Lembar terkait dengan masalah di sekolah baik dari segi } \\
\text { ketidakhadiran dan masalah ketuntasan mata pelajaran tahun } 2017 / 2018\end{array}$ \\
\hline 9 & $\begin{array}{l}\text { Bagaimana metode bermain game dalam meningkatkan motivasi belajar bahasa Inggris siswa SMAN } 1 \\
\text { Lembar kelas XI Sosial } 3 \text { tahun ajaran 2017/2018 }\end{array}$ \\
\hline
\end{tabular}

Pelaksanaan pengabdian kepada masyarakat untuk guru-guru di kabupaten Lombok Barat ini dilaksanakan di Sekolah Menengah Atas Negeri (SMAN) 1 Lembar pada tanggal 7 Desember 2017 dan diikuti oleh 30 orang guru. Pada kegiatan ini, tim pengabdian menyampaikan beberapa materi terkait dengan penulisan karya ilmiah. Materi tersebut meliputi isi Permendiknas nomor 35 tahun 2010 tentang Petunjuk Teknis Pelaksanaan Jabatan Fungsional Guru dan Angka Kreditnya, penelitian tindakan kelas (PTK), penlisan karya ilmiah, dan penyusunan laporan ilmiah.

Pembahasan permendiknas nomor 35 tahun 2010 meliputi besaran kredit terkait karya ilmiah yang diperlukan oleh seorang guru pada pangkat dan golongan tertentu apabila mengusulkan kenaikan pangkat. Selain itu, dibahas pula jenis karya ilmiah yang wajib ada. Jenis karya ilmiah tersebut seperti laporan hasil penelitian pada bidang pendidikan di sekolah/madrasahnya, yang diterbitkan/ dipublikasikan dalam majalah/jurnal ilmiah tingkat nasional yang terakreditasi, yang diterbitkan/ dipublikasikan dalam majalah/jurnal ilmiah tingkat provinsi, yang diterbitkan/ dipublikasikan dalam majalah ilmiah tingkat kabupaten/ kota, atau yang hanya diseminarkan di sekolah/ madrasahnya dan disimpan di perpustakaan. Jenis kedua adalah artikel ilmiah dalam bidang pendidikan formal dan pembelajaran pada satuan pendidikannya dan dimuat di jurnal tingkat nasional yang terakreditasi atau yang dimuat di jurnal tingkat nasional yang tidak terakreditasi/tingkat provinsi. Terakhir, jenis ketiga adalah buku pelajaran yang lolos penilaian oleh BSNP atau yang dicetak oleh penerbit dan berISBN.

Pembahasan Penelitian Tindakan Kelas (PTK) meliputi karakteristik PTK, strategi menyusun proposal PTK, pengembangan instrumen penelitian, strategi melaksanakan penelitian, hingga penyusunan laporan penelitian dan artikel hasil penelitian PTK. Sementara, pembahasan laporan penelitian meliputi sistematika dan penekanan unsur apa saja yang harus dibahas dalam setiap bagian dari laporan penelitian tersebut. Terakhir, pembahasan laporan ilmiah mencakup berbagai jenis laporan ilmiah, seperti laporan ilmiah untuk keperluan akademik (skripsi, tesis, dan disertasi), laporan ilmiah hasil penelitian, dan laporan ilmiah hasil kajian pustaka.

Hasil analisis data hasil angket menunjukkan bahwa seluruh guru belum memiliki publikasi ilmiah meskipun hampir semuanya (87\%) memerlukan publikasi ilmiah tersebut. Argumentasi yang diberikan terkait dengan belumnya memiliki publikasi ilmiah tersebut adalah tidak memiliki waktu untuk menulis (35\%) sedangkan sebagian lain mengemukakan alasan lain (26\%). Di antara mereka yang belum memiliki publikasi ilmiah tetapi sudah memerlukannya pada dasarnya berkeinginan menulis karya ilmiah tetapi mereka mengalami kesulitan. Ini dinyatakan oleh $61 \%$ peserta sedangkan sebagian kecil lainnya mengemukakan alasan lain (22\%) (Tabel 1).

Selanjutnya, terkait dengan upaya ke depan untuk mendukung terealisasinya publikasi ilmiah tersebut, pada dasarnya para peserta memiliki motivasi tinggi untuk segera menyusun karya ilmiah. Hal ini antara lain diperlihatkan oleh motivasinya yang tinggi untuk mengikuti kegiatan pengabdian ini. Tujuh puluh delapan persen $(78 \%)$ dari mereka menyatakan bahwa mengikuti kegiatan ini atas kemauan sendiri dan hanya sebagian kecil yang berdasar perintah atasan (22\%). Selain itu, mereka juga menghendaki agar kegiatan pendampingan penulisan karya ilmiah dilaksanakan dua kali setahun (48\%) dan sisanya (43\%) menghendaki sekali setahun. Mereka (61\%) juga menyatakan termotivasi untuk menulis karya ilmiah 
setelah mengikuti kegiatan pengabdian ini. Untuk mendukung publikasi ilmiah, mereka menyatakan perlu adanya jurnal ilmiah di tingkat sekolah (74\%) dan di tingkat MGMP (30\%), serta menyatakan perlu adanya kerjasama dengan perguruan tinggi (39\%) dan kegiatan pendampingan (65\%) (Tabel 1).

Antusiasme para peserta pengabdian kepada masyarakat juga diperlihatkan oleh berbagai saran yang disampaikan melalui isian angket yang kami berikan. Saran-saran konstruktif tersebut antara lain menyatakan perlunya kegiatan lanjutan dari pengabdian ini baik di tingkat sekolah maupun MGMP, penambahan frekuensi kegiatan pengabdian, mengadakan kerjasama dengan perguruan tinggi, serta sikap lebih termotivasi untuk menulis karya ilmiah (Tabel 3). Sementara, para peserta yang belum memerlukan publikasi ilmiah, pada dasarnya mereka juga berkeinginan untuk menulis tetapi mereka masih bingung untuk memulainya. Sebagian dari mereka masih berkonsentrasi pada pekerjaan-pekerjaan rutinitas guru meskipun mereka juga mengetahui belum adanya keharusan untuk berkarya ilmiah karena posisi kepangkatan dan golongannya (Tabel 4). Para peserta yang berada pada posisi pangkat dan golongan yang sudah memerlukan karya ilmiah untuk usul kenaikan pangkatnya juga menyatakan masih bingung untuk memulai menulis sehingga beberapa di antaranya menyatakan perlu adanya pendampingan seperti kegiatan pengabdian ini (Tabel 5).

Jika dianalisis lebih lanjut, para guru di kabupaten Lombok Barat pada dasarnya memiliki potensi untuk menghasilkan karya ilmiah. Hal ini antara lain diperlihatkan oleh sejumlah draf judul penelitian yang diajukan, dalam hal ini ada sembilan judul, baik secara perorangan maupun berkelompok. Dari seluruh draf judul penelitian yang diajukan, tim pengabdian menilai bahwa judul tersebut sudah layak untuk dilanjutkan kedalam kegiatan penelitian (Tabel 6).

\section{Kesimpulan}

Kegiatan pengabdian kepada masyarakat dikemas dalam berbentuk kegiatan pelatihan dan pendampingan pengembangan karya ilmiah. Materi kegiatan ini meliputi penyusunan proposal Penelitian Tindakan Kelas (PTK), pengembanan instrumen PTK, pelaksanaan PTK, penulisan laporan penelitian, serta penulisan karya ilmiah hasil PTK untuk dipublikasikan pada jurnal ilmiah lokal dan/atau nasional terakreditasi. Hasil kegiatan ini antara lain setiap peserta secara perorangan maupun berkelompok memiliki draf judul proposal PTK, proposal PTK, draf instrumen PTK, instrumen PTK, kesiapan untuk melaksanakan PTK, serta draf artikel hasil PTK untuk dipublikasikan dan kondisi minimal adalah bahwa para peserta memiliki motivasi untuk segera mengembangkan karya ilmiah baik bagi para guru yang sudah memerlukan karena posisi kepangkatan dan golongannya maupun bagi guru yang saat ini belum memerlukannya. Namun demikian, untuk menyempurnakan kemampuan guru-guru dalam kegiatan lanjutan, sebaiknya secara kontinyu tetap dilaksanakan kegiatan pendampingan dengan desain kegiatan proyek, seperti workshop. Hal ini juga diminta para peserta melalui pengisian angket pada akhir kegiatan pengabdian ini.

Akhirnya, dengan kegiatan ini diharapkan para guru di kabupaten Lombok Barat mampu mengembangkan kompotensi profesionalnya melalui kegiatan penelitian dan penyusunan karya ilmiah hasil penelitian maupun hasil kajian pustaka. Kemampuan profesionalisme ini sangat mendukung pelaksanaan tugas mengajarnya dan secara umum turut serta mengembangkan kualitas pendidikan negara kita.

\section{Saran}

Untuk kegiatan pengabdian dan upaya pembekalan tenaga pendidik dengan berbagai kompetensi profesionalnya selanjutnya, maka disarankan beberapa hal berikut: (1) sekolah memfasilitasi para guru untuk mengembangkan potensinya dalam menyusun karya ilmiah, (2) melakukan kegiatan kajian literatur atau penelitian sebagai basis dalam menyusun karya ilmiah, (3) secara kontinyu melalui sekolah atau kelompok kajian bidan ilmu, penyelenggaraan pelatihan penyusunan karya ilmiah sekali hingga dua kali setiap tahun, dan (4) sekolah memfasilitasi para guru untuk menerbitkan jurnal-jurnal pendidikan dan/atau menyelenggarakan kegiatan seminar dan/atau sejenisnya sebagai wadah untuk publikasi karya ilmiah guru.

\section{Ucapan Terima Kasih}

Kami mengucapkan terima kasih kepada Universitas Mataram melalui Lembaga Penelitian dan Pengabdian kepada Masyarakat (LPPM) yang 
telah membiayai kegiatan pengabdian ini. Selain itu, ucapan terima kasih juga disampaikan kepada Ketua Program Studi Magister Administrasi Pendidikan (prodi MAP) dan Program Pascasarjana Unram yang telah memberi kesempatan kepada kami untuk melakukan penelitian ini, serta kepada seluruh guru SLTA di kabupaten Lombok Barat yang menjadi peserta dalam kegiatan ini.

\section{Daftar Pustaka}

Bordens, K., S., and Abbott, B., B., 2014. Research Design and Methods, A Process Approach, ninth edition. New York: McGraw-Hill Education

Creswell, J. W., 2008. Educational Research, planning, conducting, and evaluating quantitative and qualitative research. USA: Pearson Prentice Hall

Nasir, Muhamad. 2015. Peraturan Menteri Riset, Teknologi, dan Pendidikan Tinggi Republik Indonesia Nomor 44 Tahun 2015 tentang Standar Nasional Pendidikan Tinggi. Jakarta: Dirjen Peraturan Perundang-undangan Kemenhum dan Hak Asasi Manusia Republik Indonesia.

Nuh, M., 2010. Petunjuk Teknis Pelaksanaan Jabatan Fungsional Guru dan Angka Kreditnya, Permendiknas no 35. Diknas RI, Kabiro Hukum dan Organisasi

Riduwan, 2013. Skala Pengukuran Variabelvariabel Penelitian. Bandung: Penerbit Alfabeta. 